УДК 351.82.639.21/.31

DOI: $10.15587 / 2313-8416.2015 .37401$

\title{
СУЧАСНА ПАРАДИГМА РЕГУЛЮВАННЯ РОЗВИТКУ ГАЛУЗЕЙ АГРАРНОГО СЕКТОРУ В УМОВАХ ГЛОБАЛЬНОГО ДЕФІЦИТУ ПРОДОВОЛЬСТВА
}

\author{
(C) Н. М. Вдовенко, Ю. А. Хижняк
}

\begin{abstract}
Ми пропонуємо сукупність цінностей, методів, підходів щеодо регулювання розвитку аграрного сектора, щุо дає можливість виділити інструменти регулювання для додаткового отримання харчових продуктів в прісній і морській воді, які закладені у виробництві риби в итучно створених, контрольованих умовах аквакультури
\end{abstract}

Ключові слова: регулювання, лічензія, галузь, аграрний сектор, виробниџтво, аквакультура, пільги, ринок, розвиток

We propose a set of values, methods, approaches to regulation of the agricultural sector that enables identification of regulatory instruments to obtain additional food in fresh and sea water, which are incorporated in the production of fish in artificial, controlled conditions aquaculture

Keywords: regulation, license, branch, agriculture, manufacturing, aquaculture, exemptions, market, development

\section{1. Встуі}

Глобальні проблеми продовольчого забезпечення населення світу все більше постають перед людством. Зростання населення планети значно випереджає приріст продовольства, а голод i недоїдання стають ризиком для здоров'я людини. У цьому контексті світ стоїть перед викликом щодо створення умов для гарантованого доступу у необхідній кількості до якісних продуктів харчування як рослинного так i тваринного походження. Вирішення даної проблеми буде залежати від раціонального використання природних та рибних ресурсів, науково-технічного прогресу, рівня державної підтримки та регулювання розвитку перспективних видів діяльності пов'язаних 3 продовольством. Актуального значення набуває питання встановлення міри повноважень ринкового i державного регулювання розвитку нових галузей в аграрному секторі економіки, враховуючи інтереси як виробників, споживачів так i держави, забезпечення збалансованості і рівноваги внутрішнього ринку даної групи товарів, а також збільшення частки насичення ринку вітчизняною продукцією того виду, яку виробники можуть виробляти самостійно.

\section{2. Постановка проблеми}

Незважаючи на значну кількість наукових досліджень щодо впливу регулювання на функціонування аграрного сектору, вони не в повній мірі дають відповіді на сучасні виклики внутрішнього і зовнішнього ринків. Ці аспекти зумовлюють не обхід-ність поглиблення наукових досліджень із проблем регулювання важливої складової рибного господарства - аквакультури. В умовах зниження промислових обсягів океанічного промислу риби до 100 млн. т, при світовій потребі у харчових рибних продуктах у 140 млн. т., стає очевидним, що лише додаткове виробництво харчової продукції у прісній i морській воді закладене в аквакультурі. Водночас, аквакультура може забезпечити постійно зростаючий попит споживачів різних країн найбільш якісною і екологічно чистою рибною продукцією. Усвідомлена турбота про здоров'я передбачає при організації раціонального харчування широке використання рибних продуктів. Риба $\epsilon$ основним сегментом виробництва i одним із головних джерел, білків, жирів, мікроелементів тваринного походження, містить мало холестерину, що особливо важливо для людини впродовж всього життя. Саме ці обставини сприяли пошуку напрямів регулювання розвитку аквакультури в Україні, написанню статті. Метою дослідження є обгрунтування методологічного забезпечення регулювання розвитку аквакультури в Україні та гарантування продовольчої безпеки у даному сегменті харчових продуктів. Предметом $\epsilon$ теоретичні та організаційно-господарські напрями регулювання розвитку аквакультури. Об'єктом дослідження є процес становлення галузі.

\section{3. Літературний огляд}

Наші дослідження дають підстави стверджувати, що економічна наукова думка формувалася у епоху, коли спостерігалися значні коливання виробництва продовольства, коли голод був розповсюдженим явищем. Це пояснює той факт, що усі цивілізації виникали біля великих водойм чи річок. Найнижча стадія дикості людства була подолана саме 3 введенням рибної їжі. Народи, що є першими носіями цивілізації, жили біля Середземного моря [1]. Лише за умови розвинутого сільського господарства, при розташуванні фермерського господарства біля багатих рибою водойм, рента землевласника відповідає не тому, що фермер може отримати від землі, а тому, що він може отримати одночасно від землі та від моря (рента входить як складова частина у ціну риби) [1]. Хоча успішність є обмеженою та невизначеною у випадку збільшення кількості, як підкреслює А. Сміт, досить важливого продукту на ринку - риби та інших водних біоресурсів, через топографію країни, близькість чи віддаленість іiі різних провінцій від 
моря, кількість їі озер та річок, багатство або бідність водойм рибою [1]. Саме земля, рудники та рибальство, вважає А. Сміт, по-перше, є головними джерелами поповнення оборотного капіталу, подруге, вимагають для своєї експлуатації як оборотного, так і основного капіталу. При цьому спостерігається феномен, коли за допомогою продукту землі витягають рибу з води [1]. Тому вперше в теоретичному i методичному плані доведено, що і за допомогою продукту води можна отримувати тваринницькі продукти “з землі”. Ми також розділяємо думку Ф. Кене, який вказував, що керівники держави разом із землевласниками та фермерами мають сприяти збільшенню продукції земель, адже від даного прибуткового джерела залежить успіх регулювання усіма галузями в державі і аграрної сфери зокрема [2]. Еволюція поглядів вчених засвідчує періоди коли втручання держави в розвиток національних економік країн було мінімальним, а також країни, періоди і галузі 3 максимальним втручанням, всеохоплюючим характером [3-12]. Безперечно, що кожна 3 країн в той чи інший період часу обирала різноманітні методи свого втручання у розвиток національних економік, але і незаперечним $\epsilon$ той факт, що всі інструменти такого впливу сформовані в теоріях щодо регулювання попиту, пропозиції, монетарної політики.

Серед значної кількості вчених, які внесли свій науковий доробок в розробку заходів впливу ми відмічаємо Й. Шумпетера [13], Дж. Гелбрейта [14], Ф. Хайека [15], Г. Саймона [16], Р. Коуза [17]. Багато відомих вчених Радянського Союзу та вітчизняних дослідників присвятили свої наукові праці проблемам формування ринкової економіки в незалежній Україні. Саме погляди науковців, дали можливість перейти від планової економіки до базових засад ринкової економіки, а потім і до формування дієздатних систем ринкової економіки. Серед них важливо також відзначити підходи I. I. Лукінова, який вказує на синтез стихійно-ринкового i свідомо державного регулювання суперечливих соціально-економічних процесів $[18,19]$. Саме його науковий доробок в комплексній оцінці інших вчених, дав можливість вибудувати для аграрного сектора України систему державних регуляторів впливу на попит та пропозицію. Науковий здобуток дає підстави стверджувати про суттєву особливість формування пропозиції на аграрну продукцію. I ця особливість $є$ для нас очевидною, тому, що вона пов'язана 3 біологічними особливостями виробництва продукції у рослинництві та тваринництві. Вона безперечно повністю перекладається і на рибне господарство, де діють традиційні закони біології, які i враховуються в нині діючих технологіях виробництва продукції. Отже, врахування біологічних закономірностей в сільськогосподарському виробництві є базовим теоретичним підходом розуміння періодичності формування пропозиції продукції. Це в свою чергу суттєво впливає на ринкову рівновагу, яка визначається між сукупним попитом і сукупною пропозицією.
4. Викладення основного матеріалу 3 повним науковим обгрунтуванням отриманих результатів

Всі напрями дослідження, які визначені у даній роботі об'єднані у задачі. Основні 3 них направлені на узагальнення еволюції теоретикометодологічних поглядів щодо регулювання розвитку аграрного сектора. Інша частина задач сформована біля оцінки стану розвитку аквакультури, як в світі, так і в Україні. Третій блок задач пов'язаний 3 пропозиціями щодо подальшого розвитку галузі 3 урахуванням рекомендацій автора. Законодавчоправова база розвитку аквакультури через заходи іiі підтримки та державне регулювання, застосування відповідних інструментів, нині формується з низки нормативно-правових актів. Важливу роль відіграють Закони України "Про основні засади державної аграрної політики на період до 2015 року” від 18.10.2005, "Про рибне господарство, промислове рибальство та охорону водних біоресурсів" від 08.07.2011, “Про аквакультуру” від 18.09.2012, “Про рибу, інші водні живі ресурси та харчову продукцію 3 них” від 06.02.2003, Постанови Кабінету Міністрів України від 11.08.2010 “Про затвердження Порядку використання коштів, передбачених у державному бюджеті для здійснення фінансової підтримки суб'єктів господарювання агропромислового комплексу через механізм здешевлення кредитів та компенсації лізингових платежів”, Указу Президента України від 03.09.2007 “Концепція вдосконалення державного регулювання господарської діяльності”.

Рівень системно-методологічної досконалості державного регулювання аквакультури нині $\epsilon$ низьким 3 точки зору його відповідності вимогам інвестиційно-інноваційної моделі розвитку. Якщо порівняти перелік заходів, затверджених постановою Кабінету Міністрів України від 23.11.2011 “Державній цільовій економічній програмі розвитку рибного господарства на 2012-2016 роки”, із постановою Кабінету Міністрів України від 19.09.2007 "Про затвердження Державної цільової програми розвитку українського села на період до 2015 року", то за своїм змістом вони досить близькі. Водночас програма розвитку села значною мірою насичена методичним та системним контекстами, про які програма розвитку рибного господарства взагалі не згадує. Крім того, Концепція Державної цільової економічної програми розвитку рибного господарства, схвалена розпорядженням Кабінету Міністрів України від 05.10.2011 зосереджена на аналізі причин виникнення проблеми та обгрунтуванні необхідності іï розв'язання саме програмним методом. Тут i виникає суттєве протиріччя, коли застосування одного методу здійснюється поза системою методів (методології). Це не сприяє процесам комплексної інтеграції аграрного сектора та аквакультури, що потребує удосконалення методологічного забезпечення державного регулювання. Цей аспект розвитку галузі, передбачає здійснювати процес удосконалення та реформування системи регулювання на єдиній концептуально-методологічній основі, а 
чіткий і збалансований розподіл функцій, повноважень та відповідальності між центральними органами виконавчої влади ще й сприятиме системності та результативності позитивних економічних процесів.

Проведений аналіз підводить до оцінки, що методологічна досконалість державного регулювання аквакультури у значній мірі $€$ похідною від рівня стандартизації виробничої та управлінської підсистем галузі з урахуванням тенденцій, обумовлених процесом входження України до глобального ринку та євроінтеграційними прагненнями держави, прискоренням адаптації до міжнародних і європейських стандартів. Нині рівень такої адаптації незадовільний, що звужує експортні можливості галузі. Провідне місце у процесах стандартизації діяльності галузі займають аспекти якості і безпеки продукції, які визначають методологічний базис національної системи державного регулювання продовольчого забезпечення населення.

Одержані показники виробництва гідробіонтів свідчать, що без людського втручання суспільство не може отримувати необхідну кількість риби. Свідченням зростання світових обсягів штучно вирощеної продукції $є$ ріст з 1 млн т в 1950 р. до понад 58 млн т у 2010 р. Світовий стан пропозиції на ринку риби протягом тривалого часу визначають Китай, Індія, Індонезія, Норвегія. Внаслідок стагнації внутрішнього виробництва риби розвинуті країни імпортують аквакультуру з країн, що розвиваються, щоб задовольнити зростаючий внутрішній попит на продукт. Доцільно згадати досвід кількох азіатських країн, зокрема республіки М'янма, де держава шляхом застосування економічних, нормативних, правових методів регулює організаційно-господарські аспекти в аквакультурі стимулює місцевих фермерів до офіційної реєстрації їх діяльності. Найбільш ефективна політика з питань залучення у кормовий сектор іноземних інвестицій розроблена у В’єтнамі. У Індонезіі, Філіппінах, Малайзії надають невеликим рибницьким господарствам кредити, податкові пільги та дотації, здійснюють тарифне регулювання, квотування. Ці країни розробили значну кількість кодексів поведінки та програми сертифікації для аквакультури, стандарти якості та безпеки продукції, відрегулювавши при цьому заходи щодо залучення іноземних інвестицій та заходи із стимулювання експорту власної продукції аквакультури. Аналіз пропозиції продукції аквакультури за регіонами показує, що Україна не входить до числа світових лідерів в сфері штучного вирощування риби. Обсяги вітчизняного вилову водних біоресурсів за останні 20 років скоротились у 5 разів. У 1989 р. внутрішні водойми забезпечили 94 тис. т вилову риби проти 37,6 тис. т виловленої, у 2011 р., 3 них - 17 тис. т вироблено в умовах аквакультури на 250 тисяч гектарів водного дзеркала 3 низькою рибопродуктивністю, яка становить 4-6 ц/га. У видовому складі вирощеної аквакультури у 2011 р. має місце зменшення виробництва коропа на $61 \%$ порівняно з 1995 р. та товстолобика, відповідно, на 32 відсотки. Рівень виробництва досяг такої межі, коли забезпечення населення України рибою, без втручання держави, в необхідних обсягах стає неможливим. Проблема полягає в дисбалансах між можливостями сировинної бази і потужностями іiі експлуатації, реальною потребою в коштах на відтворення рибних запасів і їх фактичне виділення 3 бюджету, пріоритет дрібнотоварного виробництва, відсутність матеріально-технічних засобів і фінансово-економічних інструментів впливу на ії̈ розвиток.

Наведені міркування спрямували нас на необхідність визначення чинників, які впливають на коливання рівня споживання риби у розрізі адміністративно-територіальних утворень України. Зіставлення даних на константувальному етапі дослідження дало змогу виявити ситуацію, коли у Львівській області витрати домогосподарств на продукти харчування більші ніж у Вінницькій області, проте риби споживається менше. Об'єктивна причина цього розриву певною мірою визначається доступністю населення до водних ресурсів, тобто регіональними особливостями розташування водойм, наявністю ринків рибної продукції. Аналіз показників доводить, що усунути такі коливання можливо за рахунок створення ринку оптової торгівлі у форматі багатофункціонального логістичного комплексу до складу якого входить термінал “Риба та рибопродукти". Основними напрямами регулювання розвитку ринку продукції аквакультури $\epsilon$ прогнозування та запровадження системи планування збуту риби; створення інформаційномаркетингового центру для розвитку новітньої системи державного планування; програмування рибопродуктивності та якості продукції через застосування стандартизаційних інструментів і “сертифіката походження риби". Новим інструментом аналізу пропозиції продукції як у секторі рибальства, так і аквакультури, за видовими групами та регіонами є індекс цін на рибу розроблений ФАО. Аквакультура виграє від зниження витрат на виробництво, пов'язаних із зростанням продуктивності і укрупненням масштабів, тоді як рибальство відчуває на собі негативні наслідки росту цін на енергоносії.

Ринок риби є особливо складним 3 позицій організації регулювання через специфічну продукцію, тому тут держава має використовувати інструменти стимулювання власного виробництва із зваженим обсягом імпорту риби. Імпорт продукції, складаючи 653 млн дол. у 2010 р майже в 10 разів перевищив експорт риби. Дослідження проведене ураховуючи досвід Норвегії, Ісландії, В'єтнаму, дають змогу стверджувати, що вітчизняна аквакультура у перспективі зможе функціонувати в основному без державної підтримки та вийде на рівень стабілізації та нарощування виробництва риби. Отже, перетворення аквакультури на високотехнологічний, конкурентоспроможний сектор економіки держави стримується недостатністю впровадження інновацій, недоступності залучення інвестиційних коштів і $€$ передумовою активної інтервенції іноземних компаній на вітчизняний рибний ринок та імпортозалежності. Маємо всі 
можливості прийти до висновку, що вказані проблеми зумовлені частою видозміною керівного галузевого органу, тобто через кожні 2-3 роки змінювалась система регулювання галуззю. Проте 3 1999 року, держава зробила спробу відмовитися від адміністративного втручання в діяльність рибогосподарських виробників на користь застосування економічних методів регулювання. Були створені умови для саморозвитку галузі в умовах ринку. Незважаючи на дію спеціальних режимів оподаткування, виробництво риби залишається збитковим, а галузь не вдалося вивести з кризового стану. Слід зауважити, що нині Держрибагентсвом України втрачено функцію щодо вироблення державної політики у розвитку рибного господарства. До останнього часу Держрибагентство було відсторонено від процесу розробки стандартів, без чого недієва й функція контролю. Вказане не сприяє удосконаленню регулювання аквакультури і негативно позначається й на його результативності.

Основні засади державної аграрної політики в Україні нині поширюються на сільське та рибне господарство, їх матеріально-технічне та фінансове забезпечення. Отже, є всі підстави для висновку про те, що пріоритети аквакультури мають виступати як органічна складо́ва пріоритетів розвитку аграрного сектору, ураховуючи значні обсяги видатків на рибну галузь $з$ Державного бюджету України.

Інтеграція України у світове співтовариство зумовлює необхідність системного підходу до процесів розвитку сучасних рибовідтворювальних комплексів, розроблення відповідних механізмів та застосування специфічних інструментів регулювання, які здатні забезпечити їх адаптацію до нових умов діяльності та узгодження із Указом Президента України Про Національний план дій щодо впровадження Програми економічних реформ. Вирішення піднятої проблеми полягає у створенні системи масового виробництва молоді різних видів риб (коропових, лососевих, сомових, рослиноїдних), капітальному будівництві об' єктів та технологічному переоснащенні діючих державних риборозплідників для відтворення природних популяцій у водоймах, а також формування і утримання селекційно-племінної бази для підвищення якості об'єктів аквакультури. Рибні продукти є цінними, а попит на них не може бути задоволений аналогічною продукцією інших галузей. В умовах глобалізаційних процесів обсяги виробництва і споживання риби $є$ ознакою рівня розвитку країни та пов'язані із розумінням не обхідності цієї продукції для людини.

Логічним продовженням вирішення проблеми регулювання розвитку $\epsilon$ передбачення i виділення бюджетних дотацій для аквакультури, розвитком власного кормовиробництва, удосконалення цінового механізму в системі державного регулювання аквакультури. Нині цінове співвідношення, наприлад, скумбрії до м'яса в Україні складає 1 до 1, а морепродукти, форель, стерлядь, осетер вже перевищили вартість м'яса i доводить, що рибна продукція ціниться значно вище, ніж м'ясо теплокровних тварин і птиці. Аналіз ціноутворення при надходженні коропа на український ринок, дозволяє виділити таку особливість виробництва продукції, як можливість іiі реалізації за етапами вирощування. Серед рибної продукції є така, що опосередковано впливає на кінцеву ціну готової товарної риби, зокрема личинки, мальки, цьоголітки, однорічки.

Важливою складовою частиною статті $\epsilon$ наукове обгрунтування досягнення індикаторів розвитку галузі, визначених у затвердженій Постановою Кабінету Міністрів України “Державній цільовій економічній програмі розвитку рибного господарства на 2012-2016 роки". Запропоновані напрями регулювання, в цілому, $є$ базовою платформою для досягнення країною запланованих показників вилову риби та інших водних біоресурсів загальним обсягом 375 тис. тонн. Результатами моделювання стало визначення параметрів функцій пропозиції на період до 2016 року. Відповідно до моделі очікуваного значення вилову риби у внутрішніх водоймах має скласти за оптимістичним сценарієм 68 тис. тонн. За сценарієм пасивного втручання держави - 43 тис. тонн. Умовою зростання обсягів вилову риби $є$ повне використання виробничих потужностей, збільшення рибопродуктивності водойм до рівня 15 ц/га. Слід залучити у виробництво: стави в кількості 28 тисяч штук, площею 223 тис. га., 1150 водосховищ площею 284 тисяч га, площі водойм-охолоджувачів - 15 тисяч га, які, крім спорудження на їх базі садкових та басейнових господарств, можна додатково використовувати для випасного нагулу цінних об'єктів аквакультури. Поряд із вказаним, необхідно відновити матеріально-технічну базу тепловодних господарств, а це близько 150 тис. м² садків та 600 тис. $\mathrm{m}^{2}$ басейнів. Для зниження рівня використання безпородного матеріалу низької якості у виробництві, масовий констатуючий аналіз пропонується здійснювати за показником "Реалізовано племінної молоді”, в розрізі родин та за віковими групами. Серед виконаних завдань, поставлених в статті $є$ розроблення методики обліку риби на всіх стадіях розвитку для визначення сукупної пропозиції на всіх етапах виробництва та методики визначення справедливої вартості матеріалу для розведення аквакультури і товарної риби з урахуванням цін активного ринку, і на цій основі повного узгодження 3 міжнародними стандартами, сприяння виконання умов приєднання України до СОТ та реалізації відповідних вимог СС. В умовах глобалізації, важливим завданням $\epsilon$ формування системи регулювання аквакультури на основі здійснення ліцензування діяльності у даній сфері. Система ліцензування дасть можливість уряду визначати конкретні заходи для аквакультури, забезпечувати нагляд і контроль діяльності господарюючих суб'єктів і передбачає введення додаткових функцій. 3 цією пропонуємо розширити повноваження центрального органу виконавчої влади у сфері рибного господарства в частині розроблення ліцензійних умов з урахуванням досвіду країн СС. Завдяки ліцензійним умовам, уряд визначатиме стандарти належного регулювання. 
Встановлено, що в результаті виробництва продукції аквакультури виходить новий продукт, який за характерними властивостями i ознаками відрізняється від аналогічних товарів видобутих методами рибальства. Тому постає необхідність розроблення методичних засад до створення сучасної системи ідентифікації інформації, яка дозволить розрізняти дику рибу від штучно вирощеної риби. Використання розроблених методичних підходів дало змогу здійснити розподіл між рахунками за окремими фазами економічної діяльності на рівні секцій КВЕД2010 i запропонувати до Закону України "Про аквакультуру” нову класифікацію напрямів та видів аквакультури в Україні. Зокрема, за напрямами діяльності запропоновано аквакультуру структурувати як товарну та штучного розведення (відтворення). За видами ми вирізняємо випасну, ставову та індустріальну, рекреаційну, декоративну та марикультуру. Характерною особливістю аквакультури $\epsilon$ специфічний характер самого об'єкту виробництва риби, яку вирощують у переважно контрольованих людиною умовах. Для того, щоб повністю використати цю перевагу і надати державну підтримку на розвиток цього виду економічної діяльності, необхідно бути добре поінформованими про всі зміни, які відбуваються у рибних запасах та їх видовому складі, наявних виробничих потужностях. Умовою отримання такої інформації від господарств $\epsilon$ організація обліку виробничих процесів та виловленої риби. Дослідження показали, шо вразований Державною службою статистики сучасний рівень вилову прісноводної риби в Україні останнім часом оцінюється на рівні близько 40 тисяч тонн нижчий за реальні показники.

Для покращення державного нагляду (контролю) у сфері виробництва та використання риби розроблено форму звітності № 1А-риба "Виробництво продукції аквакультури, Інструкцію та первинну документацію щодо іiі заповнення, що дасть змогу на основі чинних методичних засад розробляти прогнози та плани розвитку аквакультури. Проведені експериментальні дослідження дали змогу вперше запропонувати механізм збирання адміністративної інформації про виробництво матеріалу для розведення риби і товарної риби для наступного удосконалення галузевого регулювання.

3 огляду на перспективність галузі, внесено до Закону України "Про рибне господарство, промислове рибальство та охорону водних біоресурсів” пропозиції визнати суб'єктів аквакультури, діяльність яких пов'язана 3 розведенням, вирощуванням та переробкою власної продукції, виробниками сільськогосподарської продукції. Це сприятиме зміні оподаткування, удосконаленню механізму ціноутворення в аквакультурі, де важливу роль відіграє отримання достовірної інформації про справедливу вартість риби як біологічного активу, дасть можливість встановити нульові ставки мита на імпорт на рибні корми, обладнання, ікру, рибопосадковий матеріал, урегулювати механізми сплати за водокористування, електроенергію, землю під водою. Необхідно визначити складові механізму інвестиційного забезпечення техніко-технологічного розвитку шляхом впровадження енерго- та ресурсозберігаючих технологій для виробництва імпорттозамінних товарів. Адаптація галузі до інвестиційно-інноваційної моделі на основі сучасних агроаквагосподарств та пришвидшення процесів стандартизації також дасть змогу використовувати сучасну риборозробну техніку, враховуючи попит населення на філе риби. Переробка вторинної сировини (шкіри, луски, кісток), сприятиме розвитку нових сфер її використання.

\section{6. Висновки та перспективи подальших} досліджень

Отже, удосконалення нормативно-правової бази, впровадження інноваційних розробок, нових технологій в аквакультурне виробництво, стиму-лювання їх попиту і пропозиції з боку суспільства, має стати надійним джерелом виробництва цінної продукції, а регулювання розвитку аквакультури України спрямувати на те, щоб в Україні була запроваджена рибна ідея харчування, яка сприятиме зміцненню здоров'я нації. Новизна викладених пропозицій полягає в тому, що автором вперше обг-рунтовано необхідність надання суб'єктам аквакуль-тури статусу виробника сільськогосподарської про-дукції з відповідним реформуванням механізму державного регулювання у напрямі інтеграції аквакультури із сільським господарством; визначено сутність поняття “аквакультура" для виділення окре-мого виду економічної діяльності. На основі узагалі-нення теоретичних поглядів на предмет нашого дослідження удосконалено класифікацію видів економічної діяльності, що, порівняно з чинною, передбачає створення системи ідентифікації інформації, яка дозволить розрізняти штучно вирощену продукцію від продукції, отриманої з об'єктів дикої природи, для гармонізації вітчизняної системи регулювання й державної підтримки 3 урахуванням міжнародного досвіду; обгрунтовано механізм функціонування ринку продукції аквакультури в Україні 3 урахуванням внутрішніх потреб населення в рибі, що дає змогу посилити державний контроль у частині забезпечення виробництва й реалізації безпечної рибної продукції через впровадження “сертифіката походження риби"; запропоновано систему формування адміністративної інформації про виробництво і використання продукції аквакультури як передумови дієвого контролю за цим процесом для надання державної підтримки на розвиток даної діяльності. Тож аквакультура повинна сприйматися як рівно-правний партнер аграрного сектора, a не як друго-рядна i підпорядкована йому галузь чи виробництво, відношення до якої здійснюється за залишковим принципом.

\section{Література}

1. Смит, А. Исследование о природе и причинах богатства народов [Текст] / А. Смит. - М. : ЭКСМО, 2007. $-960 \mathrm{c}$.

2. Кенэ, Ф. Избранные экономические сочинения [Текст] / Ф. Кенэ; пер. с англ. А. В. Горбунова, Ф. Р. Каплан, Л. А. Фейгиной. - М. : Директмедиа Паблишинг, 2008. -538 с. 
3. Маркс, К. Капитал, Т. 23 [Текст] / К. Маркс, Ф. Энгельс. - М.: Госполитиздат, 1960. - 790 с.

4. Маркс, К. Капитал, Т. 25. Ч. 1 [Текст] / К. Маркс, Ф. Энгельс. Соч; изд. 2-е. - М.: Госполитиздат, 1961. - 490 с.

5. Маркс, К. Капитал. Критика политической экономии. Т. 25, Ч. 2 [Текст] / К. Маркс, Ф. Энгельс; изд. 2-е. - М. : Госполитиздат, 1961. - 460 с.

6. Про пріоритетність соціального розвитку села та агропромислового комплексу в народному господарстві: Закон України від 17.10.1990 № 400-XII [Текст] / Відомості Верховної Ради України. - 1990. - № 45. - С. 602.

7. Саблук, П. Т. Ціноутворення та нормативні витрати в сільському господарстві (теорія, методологія, практика). Т. 1 [Текст] / П. Т. Саблук; за ред. П. Т. Саблука, Ю. Ф. Мельника, М. В. Зубця, В. Я. Мессель-Веселяка. К. : ННЦ IAE, 2008. - 697 c.

8. Кваша, С. М. Рекомендації щодо можливості функціонування механізму державно-приватного партнерства у рибній галузі [Текст] / С. М. Кваша, Н. М. Вдовенко. - К.: Вітас ЛТД, 2013. - 70 с.

9. Качний О. С. Держава як орган управління і регулювання розвитку рибного господарства [Текст] / О. С. Качний // Науковий вісник Академії Муніципального управління : зб. наук. праць. - 2009. - № 4. - С. 209.

10. Козыряцкая, Я. А. Государственное регулирование и поддержка предприятий рыбного хозяйства в условиях рынка [Текст] / Я. А. Козыряцкая / Ученые записки Таврического национального университета им. В. И. Вернадского. - 2007. - Т. 20, № 1. C. $74-79$.

11. Лупенко, Ю. О. Стратегічні напрями розвитку сільського господарства України на період до 2020 року [Текст] / Ю. О. Лупенко, В. Я. Месель-Веселяк. - К. : ННЦ IAE, 2012. $-182 \mathrm{c}$

12. Бодров, В. Г. Державне регулювання економіки та економічна політика [Текст]: навч. посіб. / В. Г. Бодров, О. М. Сафронова, Н. І. Балдич. - К.: Академвидав, 2010.- $520 \mathrm{c}$

13. Шумпетер, Й. Теория экономического развития (Исследование предпринимательской прибыли, капитала, кредита, процента и цикла конъюнктуры) [Текст] / Й. Шумпетер: пер. с нем. В. С. Автономова, М. С. Любского, А. Ю. Чепуренко. - М. : Прогресс, 1982. - 455 с.

14. Гэлбрейт, Дж. Новое индустриальное общество [Текст] / Дж. Гэлбрейт; пер. с англ. - М. : АСТ, 2004. - 602 с.

15 Хайек, Ф. А. Пагубная самонадеянность. Ошиб-ки социализма [Текст] / Ф. А. Хайек; пер. с англ. Е. Оси-новой; под ред. Е. Гордеевой. - М. : Новости, 1992. $304 \mathrm{c}$.

16. Саймон, Г. А. Адміністративна поведінка: Дослідження процесів прийняття рішень в організаціях, що виконують адміністративні функції [Текст] / Г. А. Саймон; пер. 3 англ. - К. : АртЕк, 2001. - 392 с.

17. Коуз, Р. Федеральная политика по связи [Текст]/
Р. Коуз // Экономическая политика. - 2007. -№ 3. C. 111-146.

18. Лукінов, I. I. Економічні трансформації (наприкінці XX сторіччя) [Текст] / I. I. Лукінов. - К.: IH НАНУ, 1997. $-455 \mathrm{c}$.

19. Лукінов, I. І. Вибрані твори. У 2-х кн. Кн. 1 [Текст] / I. І. Лукінов. - К. : ННЦ ІАЕ, 2007. -816 с.

\section{References}

1. Smith, A. (2007). Investigation of nature and causes of wealth peoples. Moscow: Eksmo, 960.

2. Quesnay, F. (2008). Favourites Economic Works. Moscow: Dyrektmedya Pablyshynh, 538.

3. Marx, K., Engels, F. (1960). Capital. Moscow: Hospolytyzdat, 790 .

4. Marx, K., Engels, F. (1961). Capital. Moscow: Hospolytyzdat, 490.

5. Marx, K. (1961). Capital. Criticism polytycheskoy эkonomyy. Moscow: Hospolytyzdat, 460.

6. Law of Ukraine (1990). № 400-XII On the priority of social development of rural areas and agriculture in the national economy. Supreme Council of Ukraine, № 45, 602 .

7. Sabluk, P. (2008). Pricing and regulatory costs in agriculture (theory, methodology, practice). Kiev: NSC IAE, 697.

8. Kvasha, S., Vdovenko, N. M. (2013). Guidelines for the possibility of functioning public-private partnership in the fishing industry. Kiev: Vitas Ltd, 70.

9. Kachnyi, A. (2009). State as a governing body and regulation of fisheries. Scientific Bulletin of the Academy of Municipal Management: Coll Science. works, 4, 209.

10. Kozyryatskaya, J. (2007). Gosudarstvennoye regulation and support enterprises economy in terms of the market. Scientists note Taurian National University im. V. I. Vernadsky, 79.

11. Lupenko, Y. (2012). Strategic Direction of Agriculture of Ukraine for the period 2020. Kiev: NSC IAE, 182.

12. Bodrov, V. (2010). State regulation of the economy and economic policy: teach. guidances. Kiev: Akademvydav, 520.

13. Schumpeter, J. (1982). Theory of Economic Development (Study of business profits, capital, credit, interest and cycle conditions). Moscow: Progress, 455.

14. Galbraith, J. ( 2004). New Industrial State. Moscow: AST, 602.

15. Hayek, F. (1992). Fatal conceit. Errors of Socialism. Moscow: News, 304

16. Simon, G. (2001). Administrative Behavior: A Study of decision making in organizations that perform administrative functions. Kiev: Artek, 392.

17. Coase, R. (2007). Federal Politics in communication. Economic politic, 3, 146.

18. Lukin, I. (1997). Economic Transformation (late twentieth century). Kiev: IN NASU, 455. IAE, 816

19. Lukin, I. (2007). Selected Works. Kiev: NSC

Дата надходження рукопису 30.01.2015

Вдовенко Наталія Михайлівна, доктор економічних наук, доцент, кафедра глобальної економіки, Національний університет біоресурсів і природокористування України, вул. Героїв Оборони, 11, м. Київ, Україна, 03041

E-mail: nata0409@gmail.com

Хижняк Юлія Анатоліївна, здобувач, кафедра глобальної економіки. Національний університет біоресурсів і природокористування України, вул. Героїв Оборони, 11, м. Київ, Україна, 03041 